\title{
Doprinos Mary Parker Follett teoriji organizacije $i$ menadžmenta
}

\author{
Mirna Pudak* \\ UDK $\quad 65.01$ \\ 35.073.515.01 \\ 929 Parker Follet, $\mathrm{M}$ \\ Original scientific paper / izvorni znanstveni rad \\ Received / primljeno: 29.9.2016. \\ Accepted / prihvaćeno: 15.3.2017.
}

U ovom se radu prikazuje teorija Mary Parker Follett, inovativne autorice s početka 20. stoljeća, te se analizira njezin doprinos teoriji organizacije i menadžmenta. Njezina izvorna djela najprije se prikazuju kroz pregled ključnih tema o kojima je pisala, a potom se njezina teorija analizira $\mathrm{s}$ različitih aspekata. Istražuje se odnos teorije M. P. Follett prema drugim teorijama organizacije, počevši s klasičnom teorijom organizacije kojoj kronološki pripada, a nastavlja se usporedbom sa školom ljudskih odnosa i teorijom sustava, koje su joj sadržajno mnogo bliže. Zatim se razmatraju mogući razlozi neprihvaćenosti njezine teorije tijekom 20. stoljeća i sporadičnog interesa koji je za nju postojao. Usto, razmatraju se kritike upućene njezinoj teoriji, kao i njezini nedostaci. Na kraju, istražuje se širina utjecaja teorije $\mathrm{M}$. P. Follett na modernu teoriju organizacije i menadžmenta i ocjenjuje se njezina relevantnost za organizacije danas.

Ključne riječi: Mary Parker Follett, teorija organizacije, menadžment, konflikt, integracija

* Mirna Puđak, stručna specijalistica javne uprave, Zagreb (Graduated Expert Specialist of Public Administration, Zagreb, Croatia, e-mail: mirna.pudjak@gmail.com). 


\section{Uvod}

U ovom se radu prikazuje i analizira doprinos Mary Parker Follett teoriji organizacije i menadžmenta. Follett je djelovala na početku 20. stoljeća, u doba klasične teorije organizacije, no svojim izraženim humanističkim i sistemskim pristupom od nje je značajno odstupala. Iako je tijekom života bila priznata i utjecajna autorica na područjima političke znanosti, organizacije i menadžmenta, nakon smrti njezina teorija pada u zaborav te se tek nakon sredine 20. stoljeća ponovo počinje pojavljivati interes za njezin rad. Iako je tijekom 20. stoljeća njezina teorija nerijetko bila marginalizirana, mnogi autori smatraju da je bila daleko ispred vremena u kojem je pisala. ${ }^{1}$

Prvi dio rada prikazuje teoriju M. P. Follett kroz pregled ključnih tema o kojima je pisala, pri čemu su kao izvori korištena njezina originalna djela. Drugi dio rada analiza je njezina doprinosa teoriji organizacije i menadžmenta, podijeljena u dvije cjeline: u prvoj je prikazan odnos M. P. Follett prema drugim teorijama organizacije koje su za nju relevantne, najprije usporedbom s klasičnom teorijom organizacije i školom ljudskih odnosa, te naposljetku prikazom njezina preciznog predviđanja bitnih elemenata teorije kompleksnih sustava. Druga cjelina prikazuje Follett u širem kontekstu, razmatrajući moguće razloge neprihvaćenosti njezine teorije tijekom 20. stoljeća, kao i njezine kritike i nedostatke. Pored toga, razmatra se i širina njezina utjecaja na modernu teoriju organizacije i menadžmenta. Na kraju, ocjenjuje se relevantnost njezine teorije za organizacije danas.

\section{Pregled teorije Mary Parker Follett}

Opus Mary Parker Follett relativno je skromnog opsega, no njegov utjecaj na teoriju organizacije i menadžmenta danas se smatra neprocjenjivim (Metcalf \& Urwick, 2013). Njezin doprinos teoriji organizacije i menadžmenta ${ }^{2}$ sadržan je primarno u djelima The New State (1918) i Creative

\footnotetext{
${ }^{1}$ Warren Bennis, začetnik moderne teorije vođenja, ističe da »sve što je danas napisano o vođenju i organizacijama dolazi iz zapisa i predavanja Mary Parker Follett« (Bennis, 2003, str. 178).

${ }^{2}$ U ranijim fazama svoje karijere Follett se bavila političkom znanošću i filozofijom. Kao najznačajnije djelo iz tog razdoblja ističe se The Speaker of the House of Representatives iz 1896.
} 
Experience (1924), te u nizu objavljenih članaka i održanih predavanja. ${ }^{3}$ Kao kriterij pregleda njezine teorije izabrala sam ključne teme o kojima je pisala, budući da su iste teme, uz određena odstupanja, prisutne u gotovo svim njezinim djelima. U tom smislu, njezina teorija je vrlo konzistentna - mijenja se jedino područje interesa - pa se tako The New State bavi pitanjima demokracije, građanske participacije, odnosa pojedinca i zajednice te organizacije građanskog života u povezanim susjedskim grupama. Creative Experience, pak, istražuje kompleksnu dinamiku međuljudskih odnosa kroz pojmove kružne reakcije, kružnog ponašanja i totalne situacije, koristeći se kao temeljem elementima Gestalt psihologije. Usto, predlaže integraciju kao najpoželjniji oblik ljudske suradnje u organizacijama, pri čemu je iskustvo svakog njezina člana vrijedan doprinos organizaciji. Također, tvrdi da je iskustva potrebno povezati i interpretirati na konstruktivan način, što zahtijeva stalno učenje i prilagodbu. Uvodi i pojam power with, koncept moći koju članovi organizacije razvijaju zajednički. Kasniji radovi odraz su orijentacije M. P. Follett na pitanja menadžmenta - ideje razvijene u prethodnim djelima izlaže na koncizniji način, no načela na kojima počivaju ostaju ista. Također, aktivnije se bavi pitanjima koordinacije i kontrole, timskog rada i vođenja u organizaciji.

\subsection{Bogatstvo različitosti i vrijednost svakog iskustva}

Follett je karijeru u javnoj sferi započela 1900. godine na lokalnoj razini u Bostonu (Metcalf \& Urwick, 2013), organizacijom edukacijskih i rekreacijskih sadržaja za tamošnje siromašno stanovništvo u okviru tzv. školskih centara - korištenjem prostora bostonskih škola nakon nastave za izvođenje tih sadržaja. Centri su nudili sadržaje za stanovnike određenog susjedstva, pri čemu su u njihovu planiranju i provedbi sudjelovali upravo ti stanovnici (Follett, 1918). Follett je primijetila da susretanje i suradnja ljudi različitih kultura, porijekla, uvjerenja i osobnosti otvara put stvaranju novih sadržaja i novih vrijednosti, u smislu zajedničkih rješenja za probleme zajednice. Pritom je uočila da se u tom procesu oslobađa kreativna energija i razvija osjećaj zajedništva. Upravo su ta kreativna energija, odnosno zanimljivost i kompleksnost međuljudskih odnosa za nju ključni elementi u proučavanju organizacije i na tim temeljima gradi svoju teoriju organizacije. Follett smatra da je čest razlog zbog kojeg se ljudi nevoljko

${ }^{3}$ Značajni radovi iz tog razdoblja dostupni su u zbirkama Dynamic Administration (1940) i Freedom \& Co-ordination (1949), koje su objavljene posthumno. 
upuštaju u suradnju zapravo strah od konflikta te pritom naglašava da je »strah od različitosti strah od samog života« (Follet, 1930, str. 301).

Suprotno organizacijskim trendovima svoga vremena, Follett smatra da ekspertno znanje nema primat u organizaciji, jer kada bi se problemi rješavali tako lako, sve što bismo trebali je uvesti dovoljno »znanstvenog menadžmenta u tvornice, dovoljno specijalista (za transport, higijenu i sl.) u gradove, dovoljno formula s fakulteta u poljoprivredu i život bi postao ugodnim i lijepim« (Follett, 1930, str. 3). Za Follett, svaki čovjek predstavlja integralan dio društva i njegovo specifično iskustvo potrebno je povezati s iskustvima drugih (Follett, 1930). Prema tome, ne moramo sami postati ekspertima da bismo mogli naučiti razumjeti ekspertno mišljenje i primijeniti ga na vlastito iskustvo. Follett smatra da je potrebno razvijati kooperativno iskustvo, kao uzajamnu suradnju na svim poljima društvenog života (Follett, 1930).

\subsection{Kružna reakcija}

Za razumijevanje teorije Mary Parker Follett neizostavan je koncept kružne reakcije (circular response), odnosno kružnog ponašanja (circular bebaviour). Cilj im je pokazati da ponašanje nije moguće promatrati statično i odvojeno od okoline u kojoj se odvija te objasniti dinamičnu, kompleksnu prirodu međuljudskih odnosa. Ponašanje, dakle, nije dovoljno promatrati samo kao izoliranu reakciju na neposredni podražaj ili linearan slijed takvih podražaja i reakcija. U odnosu između dvoje ljudi ponašanje jedne osobe ne nastaje samo kao reakcija na ponašanje druge osobe - ono nastaje kao dinamična mreža međusobnog kružnog utjecaja. Follett objašnjava mehanizam kružne reakcije na primjeru igre tenisa: »A servira. Način na koji B vraća loptu djelomično ovisi o načinu na koji mu je servirana. Sljedeći potez koji A napravi ovisit će o njegovom originalnom servisu plus načinu na koji ga je B vratio i tako dalje« (Metcalf \& Urwick, 2013, str. 44). U tom odnosu ponašanje jedne osobe konstantno utječe na ponašanje druge osobe, i obratno, pri čemu se obje nepovratno mijenjaju. Svojim ponašanjem mijenjaju jedna drugu, čime mijenjaju svoju okolinu, no i sama ih okolina istovremeno mijenja i utječe na njih - neprestana promjena u srži je svakog odnosa. Neposredan podražaj, prema tome, nije glavni faktor koji determinira određeno ponašanje (Follett, 1930). Ono što je važno jest sveukupna situacija (total situation), koju Follett definira kao »sveukupnost aktivnosti u kojoj se aktivnosti pojedinca i aktivnosti okoline neprestano isprepleću « (Follett, 1930, str. 106), pri čemu je neposredni 
podražaj samo jedan od dijelova koji čine cjelinu. Drugim riječima, »reagiramo na podražaj koji smo sami pomogli stvoriti« (Metcalf \& Urwick, 2013, str. 194).

\subsection{Konstruktivni konflikt i integracija}

Svaki pojedinac integralan je dio organizacije, smatra Follett, no pojedinci se nedvojbeno razlikuju. Te različitosti neizbježno vode do pojave konflikta koji Follett smatra samo susretanjem različitosti - kao takav, on nije niti dobar niti loš. Budući da je nezaobilazan, potrebno ga je iskoristiti na konstruktivan način - integracijom konfliktnih pozicija. Za razliku od dominacije i kompromisa, koje Follett smatra nezadovoljavajućim rješenjima (Follett, 1930), integracija je način rješavanja konflikta u kojem su želje svake strane zadovoljene, jer se njome stvara novo rješenje koje ih ujedinjuje.

Kako postići integraciju? Follet predlaže nekoliko koraka: prije svega, »staviti karte na stol, suočiti se s pravim problemom, razotkriti konflikt i iznijeti cijelu stvar na otvoreno « (Metcalf \& Urwick, 2013, str. 38). Ono što iznošenje svih bitnih interesa, želja, različitosti i neslaganja pruža jest mogućnost njihove reevaluacije. Sljedeći korak je rastavljanje zahtjeva svake strane na sastavne dijelove. To uključuje pažljivu analizu problema da bi se moglo razlučiti bitno od nebitnog, »zagrepsti« dublje ispod površine i otkriti pravi uzrok konflikta. Rastavljanje konflikta djeluje protivno formiranju suprotstavljenih strana u nekom problemu. Umjesto razmatranja problema u cjelini, pri čemu je lakše upasti u zamku rasuđivanja na temelju emocija, predrasuda ili generalizacija, kada se razmatraju manji, konkretniji problemi, lakše je razmotriti konkretne činjenice vezane uz njih i vidjeti ih onakvima kakve doista jesu (Metcalf \& Urwick, 2013).

Follett integraciji pridaje progresivnu kvalitetu. Naime, ako neslaganja oko određenog pitanja uspijemo integrirati, sljedeće neslaganje, odnosno konflikt, nastat će na višoj razini te će od samog početka biti kvalitetniji (Metcalf \& Urwick, 2013). Tako se i sljedeća integracija događa na višoj razini - proces integracije time osigurava kontinuirani napredak. Konflikt, dakle, ne postaje konstruktivan, niti različitosti automatski dovode do integracije samim svojim postojanjem i susretanjem. Follett u svojim djelima kontinuirano naglašava da je postizanje integracije proces koji zahtijeva stalno učenje. Iako se u različitostima nalazi velik potencijal, on može biti ispunjen samo svjesnom i koordiniranom ljudskom akcijom. 


\subsection{Zakon situacije - nevidljivi vođa}

Kad je riječ o vođenju u organizaciji, Follett nudi jedinstveni koncept zakona situacije kao nevidljivog vođe. Ističe nedostatke koji proizlaze zbog izdavanja naredbi »odozgo«, od menadžmenta, bez mogućnosti povratnog utjecaja radnika na pitanje o kojem se odlučuje. Prvo, takav način izdavanja naredbi ne osigurava legitimnost potrebnu za njihovo kvalitetno izvršavanje. Ako se od radnika očekuje da slijepo izvrši svaku naredbu, potkopava se njegova stručnost, narušava njegovo dostojanstvo te produbljuje jaz između menadžera i radnika (Metcalf \& Urwick, 2013).

Drugo, oštro odvajanje između razina upravljanja i izvršavanja zadataka praktično je nemoguće. Kod većine profesija, čak i obavljanje jednostavnih zadataka u određenoj mjeri uvijek ovisi o diskreciji radnika, o njegovoj osobnoj procjeni najboljeg načina obavljanja posla u danom trenutku, koja je utemeljena na njegovu znanju i iskustvu. Prema tome, »radnici ponekad upravljaju« (Metcalf \& Urwick, 2013, str. 85), čak i kad formalno nemaju tu dužnost. Follett čak i riječi »podređen« i »nadređen« smatra štetnima, jer često mogu neopravdano izazvati dojam superiornosti (Follett, 2013). U mnogim slučajevima, podređeni ima veća znanja o određenom pitanju od nadređenog, kojem je potreban njegov savjet, što granicu između podređenosti i nadređenosti u najmanju ruku čini mutnom.

Kako stati na kraj proizvoljnom, nelegitimnom autoritetu? Kako okončati podijeljenost između menadžera i radnika? Podvrgavanjem zakonu situacije. To znači depersonalizirati naredbe i organizirati posao tako da mu svaki član organizacije svojim radom pridonosi kao njezin integralni dio. U takvoj organizaciji autoritet ne izlazi iz formalnog položaja, nego iz činjenica važnih za situaciju - činjenica koje menadžer i radnik prikupljaju i razmatraju zajednički. Follett tvrdi da »jedna osoba ne bi trebala drugoj davati naredbe, obje bi trebale primati naredbe iz situacije« (Metcalf \& Urwick, 2013, str. 59).

\subsection{Funkcionalno ili integrativno jedinstvo}

Koncept funkcionalnog jedinstva odnosi se na pitanje odnosa između različitih dijelova organizacije i njihova odnosa prema organizaciji kao cjelini. Funkcionalno jedinstvo postoji u organizaciji čiji su dijelovi međusobno usklađeni te zajedno čine cjelinu koja je različita od njihova zbroja (Metcalf \& Urwick, 2013). To shvaćanje Follett povezuje s teorijom Gestalt škole psihologije, prema kojoj nije moguće objasniti nečiju osobnost 
kao cjelinu tumačenjem pojedinačnih osobina, niti je moguće svesti je na njihov zbroj. Pojedinačna osobina dobiva svoje puno značenje tek kroz razumijevanje njezina odnosa sa svim ostalim osobinama (Follett, 1930). Isti princip, smatra Follet, vrijedi i za odnose među dijelovima organizacije. U organizaciji s mnogim odjelima, primjerice, ne postoji problem koji se tiče samo jednog odjela - svi dijelovi organizacije u stanju su međuovisnosti, a o kvaliteti njihove koordinacije ovisi uspjeh organizacije.

Follett opisuje stvaranje funkcionalnog jedinstva kao dinamičan proces kontinuiranog usklađivanja dijelova cjeline međusobno i dijelova sa samom cjelinom. Taj proces uključuje kružno ponašanje između dijelova i integraciju kao rezultat tog ponašanja, no ne i krajnji rezultat procesa, jer se proces odvija kontinuirano i progresivno (Metcalf \& Urwick, 2013), pri čemu jednom postignuta integracija otvara put stvaranju nove integracije i novog funkcionalnog jedinstva.

\subsection{Moć}

Follett piše o dvije vrste moći: prva, koju naziva nadmoć (power over), odnosi se na vrstu moći kakvom se najčešće shvaćala u tadašnjoj teoriji i praksi - »moć jedne osobe ili grupe nad drugom osobom ili grupom« (Metcalf \& Urwick, 2013, str. 101). Nasuprot njoj, Follett nudi svoje poimanje moći, odnosno moć kakvu bi svaka organizacija trebala graditi, a to je zajednička moć (power with), odnosno zajednički stvorena moć (Metcalf \& Urwick, 2013). Moć koja je stečena nametanjem izvana, bilo uvjeravanjem, prisilom ili kojim drugim načinom, nije legitimna jer ne odgovara zakonu situacije, ne uključuje interese svih, nego samo interese one strane koja stječe moć na račun druge. ${ }^{4}$

Ipak, nadmoć nije moguće potpuno iskorijeniti iz organizacije, no moguće ju je bitno reducirati (Metcalf \& Urwick, 2013) na tri načina: podvrgavanjem zakonu situacije, integracijom i djelovanjem po principu funkcionalnog jedinstva. Zajedničku moć, prema tome, stvaraju svi članovi organizacije - ona označava »udruženi kapacitet grupe« (Metcalf \& Urwick, 2013, str. 248). Organizacije se moraju okrenuti razvoju onih metoda koje će graditi taj kapacitet. To zahtijeva promjenu stava prema moći, odnosno uklanjanje negativnih konotacija vezanih uz sam pojam moći. Kao što pojavu konflikta treba promatrati vrijednosno neutralno, prije nego njegovo

4 »Moć prisile predstavlja propast svijeta, a moć suradnje bogatstvo i napredak svake ljudske duše.« (Follett, 1930, str. xiii). 
rješavanje poprimi konstruktivan ili destruktivan predznak, tako i moć postaje pozitivna ako je izgrađena zajednički.

\subsection{Timski rad i uloga vođe u organizaciji}

Follett timski rad smatra aktivnim i kreativnim procesom jer vjeruje da su ljudi »sposobni sami graditi svoj život« (Follett, 1918, str. 8). Organizacije bi, prema tome, trebale usvojiti rad u timovima. U skladu s njezinim poimanjem funkcionalnog jedinstva, Follett vjeruje da je svaki član tima dužan dati vlastiti doprinos grupnom pothvatu. Samo u tom slučaju možemo govoriti o pravom timskom radu.

Timski rad ne isključuje postojanje vođe u formalnom smislu, no njegova uloga bitno se mijenja u odnosu na tradicionalnu. $U$ vremenu u kojem je Follett pisala prevladavalo je mišljenje da se vođe rađaju, a ne stvaraju, odnosno da se vještine potrebne za vođenje ne mogu naučiti. Argumenti kojima Follett opovrgava tu teoriju jesu: prvi, svaka osoba ima određeni kapacitet za vođenje koji se može razvijati učenjem, i drugi, različite situacije zahtijevaju različite tipove vođenja. Drugim riječima, u danom trenutku vođom postaje ona osoba koja pokaže najbolje razumijevanje okolnosti određene situacije (Metcalf \& Urwick, 2013).

Dobar vođa je onaj koji dobro poznaje svoj posao, koji sebe i svoje podredene podvrgava zakonu situacije, a ne vlastitoj volji. Njihov odnos temelji se na kružnom ponašanju - vođa vodi tim i vođen je timom (Metcalf \& Urwick, 2013). Vođa je član tima koji nosi najveću odgovornost za stvaranje funkcionalnog jedinstva, njegova je dužnost probuditi kreativnu energiju među članovima tima i latentni potencijal koji se krije u svakom pojedinom članu. Njegov posao je »organizirati iskustvo svih članova i pretvoriti ga u zajedničku moć« (Metcalf \& Urwick, 2013, str. 258). On ima zadatak povezati konkretne vještine i sposobnosti svog tima s potrebama organizacije i društva, te jasno pokazati tu vezu svakom pojedinom članu. Time će se povećati produktivnost i, još važnije, članovi tima svoj će rad doživljavati svrhovitim. Follett, naime, dobrobit organizacije smatra istovjetnom dobrobiti društva i ne vjeruje da organizacija može dugoročno opstati ako ne djeluje u korist zajednice (Metcalf \& Urwick, 2013).

\subsection{Kontrola i koordinacija}

Za Follett, cilj je organizacije »kontrola kroz efektivno jedinstvo « (Metcalf \& Urwick, 2013, str. 184). Da bi kontrola nad određenom situacijom bila 
moguća, nužna je kooperacija svih koji su u nju uključeni, a stupanj kontrole ovisit će o tome koliko su uspješno njihove ideje integrirane, odnosno, do koje je mjere razvijeno funkcionalno jedinstvo. Kao što je čovjeku potrebna koordinirana akcija mišića da bi imao kontrolu nad vlastitim pokretima, navodi Follett, tako je i organizaciji potrebna koordinirana akcija njezinih članova da bi imala kontrolu nad situacijama u kojima se nalazi. U tom kontekstu kontrolu je nemoguće nametnuti izvana - ako postoji funkcionalno jedinstvo, postoji i kontrola. Drugim riječima, interakcije kojima se ostvaruje funkcionalno jedinstvo (kružno ponašanje, integracija) jesu kontrola - organizacija je sustav koji sam sebe kontrolira (Metcalf \& Urwick, 2013).

Kontrola je također usko povezana s koordinacijom - ona se postiže koordinacijom. Koordinacija označava stvaranje funkcionalnog jedinstva. Follett navodi četiri načela koordinacije: koordinacija se ostvaruje direktnim kontaktom; koordinacija mora započeti u ranim fazama procesa; koordinacija je recipročan odnos svih faktora u situaciji; te koordinacija je kontinuirani proces (Metcalf \& Urwick, 2013).

\subsection{Temeljna načela organizacije}

Na kraju, navodim četiri načela organizacije koja Mary Parker Follett ističe kao temeljna. Prvo načelo odnosi se na oslobađanje (evoking) skrivenih kapaciteta svakog člana organizacije. Ono se događa u okviru kreativnog procesa interakcije za koji se Follett zalaže. To je interakcija na načelu kružnog ponašanja, pri čemu svaki član ima priliku utjecati na drugog te osloboditi kreativnu energiju pojedinca i grupe. Ovo načelo temelj je koordinacije, jer da bismo mogli ujediniti kapacitete ljudi u organizaciji, moramo najprije otkriti s kakvim kapacitetima raspolažemo (Metcalf \& Urwick, 2013). Drugo temeljno načelo je sama interakcija, koja treba biti dinamična i utemeljena na kružnom ponašanju, a treće integracija, o kojoj je potanko bilo riječi prije. Posljednje načelo Follett naziva izranjanjem (emerging) i odnosi se na pojavu novih vrijednosti koje nastaju integracijom, na novu prirodu cjeline, različite od dijelova koji ju čine. Ovo načelo potvrđuje progresivnu prirodu integracije. Jedno funkcionalno jedinstvo pojavom novih vrijednosti dovodi do nastanka novog jedinstva i tako dalje - to je »progresija koja stvara samu sebe« (Metcalf \& Urwick, 2013, 201). Ta načela Follett ne promatra odvojeno, kao faze u procesu. Naprotiv, oslobađanje, interakcija, integracija i izranjanje odvijaju se istovremeno i samo su »različiti aspekti istog procesa« (Metcalf \& Urwick, 2013, str. 198). 


\section{Analiza doprinosa Mary Parker Follett teoriji organizacije i menadžmenta}

\subsection{Odnos prema drugim teorijama organizacije}

Upoznajući se s opusom M. P. Follett, lako je vidjeti zašto je neki autori ${ }^{5}$ nazivaju proročicom. Mnoge od njezinih ideja anticipiraju smjerove u razvoju teorije organizacije koji su se pojavljivali desetljećima nakon njezina vremena. I dok su njezini suvremenici organizaciju promatrali mehanicistički, smatrajući je nalik stroju, Follett je težište svoje teorije stavila na kreativnu organizaciju odnosa među ljudima. Time je ne samo nagovijestila pojavu sljedeće velike faze u razvoju teorije organizacije - škole ljudskih odnosa nego ju je i nadišla, otvarajući svojim razmišljanjima put prema teoriji sustava. Usto, služeći se saznanjima s područja psihologije, sociologije, filozofije, prava, ekonomije, političke znanosti, biologije, matematike i umjetnosti, ${ }^{6}$ kako bi potkrijepila svoju teoriju, svjedoči njezinom izraženom interdisciplinarnom pristupu organizaciji. Follett stoga nije moguće potpuno smjestiti ni u jedan od smjerova u teoriji organizacije jer njezin opus predstavlja kombinaciju obilježja klasične teorije organizacije, škole ljudskih odnosa i teorije sustava (Parker, 1984).

Klasična teorija organizacije i škola ljudskib odnosa. Početkom 20. stoljeća teorijom organizacije u Americi dominirao je Taylorov znanstveni menadžment, utemeljen na pretpostavci da za obavljanje svakog posla postoji samo jedan najbolji način, do kojeg je moguće doći primjenom znanstvene metode. Taylor je radni proces rastavio do najsitnijih dijelova radi brzog i pojednostavljenog učenja radnih zadataka te je iz njega izveden pojam poštenog dnevnog rada koji obavlja prvorazredni radnik, čovjek koji svoj maksimum može ispuniti samo na jednom, točno određenom radnom mjestu u skladu sa svojim sposobnostima (Perko-Šeparović, 1975). Follett je organizaciji pristupila s posve drugog aspekta - ljudski je, a ne tehnički faktor smatrala presudnim. Osim toga, njezini pogledi na položaj radnika nisu bili fiksni kao Taylorovi jer je smatrala da se potencijali radnika trebaju kontinuirano razvijati. Međutim, sama ideja znanstvenog pristupa problemu upravljanja organizacijom u načelu je kompatibilna s idejom

\footnotetext{
${ }^{5}$ Zbirka Mary Parker Follett: Prophet of Management koju je uredila P. Graham jedan je od poznatijih primjera.

${ }^{6}$ Primjerice, Follett ilustrira odnose dijelova u funkcionalnoj cjelini na primjeru rada orkestra i strukture stihova u poeziji (Metcalf \& Urwick, 2013).
} 
zakona situacije koju Follett zagovara, budući da, u teoriji, znanstveni menadžment depersonalizira naredbe (Metcalf \& Urwick, 2013). Time posljednju riječ u upravljanju imaju znanstveno utvrđene činjenice koje služe kao pokazatelji optimalnog načina rada, odnosno rječnikom Mary Parker Follett, činjenice koje tvore zakon situacije. Međutim, dok je kod Taylora za utvrđivanje tih činjenica zadužen isključivo viši menadžment, Follett taj zadatak povjerava svim članovima organizacije.

Više sličnosti Follett dijeli s H. Fayolom, koji je djelovao u Europi gotovo istovremeno kad i Taylor, no umjesto na operativnu razinu, usredotočio se na razinu upravljanja. U svom najpoznatijem djelu Opće $i$ industrijsko upravljanje, iz 1916. godine, iznosi jedinstvenu teoriju upravljanja prema kojoj je upravljanje kao djelatnost uvijek podložno istim načelima, bez obzira na tip organizacije o kojoj je riječ (Perko-Šeparović, 1975). Ideja je to koju, u određenoj mjeri, dijeli s Follett. Naime, i ona je smatrala da svaka organizacija u biti djeluje po istim načelima, što se osobito vidi iz njezine sinteze temeljnih načela organizacije, no njihova načela sadržajno se razlikuju. Primjerice, Fayolova načela, kao što su hijerarhijska linija komunikacije, autoritet u smislu prava naređivanja i traženja poslušnosti ili jedinstvo komande i usmjeravanja, izravne su prepreke ostvarivanju funkcionalnog jedinstva koje Follett smatra ključnim. Ona predstavljaju kontrolu koja dolazi izvana, umjesto kontrole koja se ostvaruje organski, što je potrebno za jedinstvo o kakvom Follett piše.

Škola ljudskih odnosa ${ }^{7}$, s druge strane, dotiče problematiku o kojoj Follett piše. Na prvi pogled, njezine ideje sliče idejama škole ljudskih odnosa - međuljudski odnosi i zadovoljstvo radnika tim odnosima ključni su za motivaciju i produktivnost, a radnike je potrebno uvažavati kao cjelovite osobe, čije potrebe nisu samo ekonomskog karaktera. Osnovna razlika je u tome što Follett razmišlja mnogo šire. Za razliku od škole ljudskih odnosa, koja organizaciju promatra kao složen, ali zatvoren sustav (Perko-Šeparović, 1975), Follett piše o organizacijskoj okolini (Metcalf \& Urwick, 2013). I dok škola ljudskih odnosa, kao i Follett, ističe važnost kooperacije koja se najbolje može ostvariti timskim radom (Miner, 2006), njihove se zamisli o tome kako se kooperacija ostvaruje i što ona točno znači razlikuju. E. Mayo konflikt smatra »zlom, simptomom manjka socijalnih vještina«, te mu suprotstavlja kooperaciju kao pokazatelj zdravih međuljudskih odnosa (Leavitt et al., 1989, str. 521), dok Follett upravo u konfliktu vidi

7 Odnosi se na tzv. Hawthorne studije koje su proveli E. Mayo i njegovi suradnici između 1920-ih i 1950-ih godina i teoriju koja je nastala interpretacijom tih istraživanja (Miner, 2006). 
potencijal za kooperaciju. Općenito, Follett nudi cjelovitiji prikaz kompleksnosti međuljudskih odnosa od škole ljudskih odnosa i konkretnije načine postizanja kooperacije, uzimajući u obzir složenu mrežu utjecaja između pojedinaca i njihove okoline (Follett, 1930).

Teorija sustava. Shvaćanje prema kojem je organizacija »skup dijelova koji su u međusobnom odnosu i čine jednu cjelinu, različitu od njenih sastavnih dijelova « (Perko-Šeparović, 1975, str. 37), u teoriji organizacije uzima zamah sredinom 20. stoljeća (Yuksel, 2015). Follett je organizaciji pristupila na taj način još u dvadesetim godinama 20. stoljeća. Za razliku od autora mehanicističkog smjera, koji su organizaciju vidjeli kao statičan sustav u kojem kontrola dolazi izvana, odnosi su hijerarhijski te prevladava topdown pristup upravljanju, Follett je organizaciju prikazala kao kompleksni adaptivni sustav (Yuksel, 2015). Takav sustav karakterizira nelinearna dinamika ${ }^{8}$, odnosi su heterogeni, prisutan je bottom-up pristup upravljanju, a kontrola se ostvaruje autoregulacijom (Yuksel, 2015). Organizacija kao kompleksni sustav time postaje »mreža društvenih interakcija (Goldstein et al., 2010, prema: Yuksel, 2015, str. 528) u kojoj »raznovrsnost potiče evoluciju koja rezultira nastankom procesa na višoj razini koji omogućavaju prilagodbu. Evolucija je vjerojatna kada je dinamika interakcije fluidna, a raznovrsnost, tenzija i konflikt utkani u uzorke komunikacije« (Stacey, 2001, prema: Yuksel, 2015, str. 528).

Iako se ne koristi istom terminologijom, kada piše o progresivnoj prirodi integracije (Follett, 1930), Follett prikazuje organizaciju upravo kao kompleksni adaptivni sustav s međuljudskim odnosima u središtu. Integracija koja nastaje iz različitosti i konflikta u tom smislu predstavlja nastanak procesa na višoj razini te Follett pritom naglašava da je to proces koji se odvija kontinuirano i organski, čime upućuje na autoregulacijska svojstva organizacije koja prikazuje kroz svoje viđenje koordinacije i kontrole. Bottom-up pristup osobito se vidi u njezinu konceptu zajedničke moći i stavovima o vođenju u organizaciji. Osim toga, Follett navodi izranjanje kao jedno od temeljnih načela organizacije, kojim označava pojavu novih vrijednosti koje nastaju integracijom. Izranjajuće ponašanje također je obilježje kompleksnih sustava, u smislu novih, nepredvidljivih ishoda, koji nastaju tijekom interakcije različitih elemenata u kompleksnom sustavu i omogućuju njegovu prilagodbu (Yuksel, 2015). Na kraju, njezin koncept kružne reakcije zapravo opisuje nelinearnu dinamiku (Yuksel, 2015), jer

\footnotetext{
8 Teorijska perspektiva unutar moderne teorije sustava, usko vezana uz teorije kaosa. Proučava sustave koji se »mijenjaju na način koji nije podložan linearnim uzročno-posljedičnim modelima« (Halmi, 2002, str. 133).
} 
je osnovna karakteristika kružne reakcije upravo nelinearnost - ponašanje koje nije rezultat linearnih, izoliranih podražaja i reakcija, nego dinamična mreža utjecaja između pojedinaca i njihove okoline.

\subsection{Mary Parker Follett u širem kontekstu - njezina teorija nekad i sad}

Mogući razlozi nepribvaćenosti, kritike i nedostaci. Teorija M. P. Follett nije uvijek nailazila na odobravanje. Iako je progresivna era u jednoj mjeri bila pogodna klima za njezine humanističke ideje (Feldheim, 2004), što se očituje uspjehom djela The New State i Creative Experience, dominantna teorija organizacije ipak je ostao znanstveni menadžment te je Follett nedugo nakon smrti pala u zaborav. Orijentacija na centralizaciju i efikasnost u tridesetim i četrdesetim godinama 20. stoljeća radi oporavka američkog gospodarstva od depresije i sudjelovanja u Drugom svjetskom ratu, umanjila je šanse za prihvaćanje njezinih ideja. U tom kontekstu, one su djelovale radikalno, čak i subverzivno (Feldheim, 2004), budući da se participativna demokracija na lokalnoj razini kakvom je Follett opisuje potpuno kosi s idejom jake centralne vlasti.

Problematičnim se pokazalo i pitanje moguće diskriminacije na temelju spola (Miner, 2006). Jesu li njezine ideje zanemarene zato što je bila žena ili možda zato što je njihov sadržaj uključivao tipično »ženske« vrijednosti, koje se nisu uklapale u sliku menadžmenta kojim dominiraju muškarci (Feldheim, 2004)? Odgovor na to pitanje nije jednostavan. S jedne strane, Follett je uživala poštovanje (pretežno muških) kolega te bila tražena savjetnica menadžera u industriji, no s druge strane ostaje činjenica marginalizacije njezine teorije nakon smrti. Mogućim razlogom za to mogla bi biti tzv. ciklička popularnost njezine teorije (Witt, 2007). Na nacionalnom planu, promjenjivi politički i gospodarski uvjeti nepovoljno djeluju na ostvarenje njezinih ideja - u kriznim vremenima države se okreću centralizaciji i hijerarhijskom organizacijskom ustroju (Witt, 2007), čime radikalni, bottom-up pristup, koji je Follett zagovarala, postaje neprimjenjiv sve do ponovne decentralizacije. Uzevši to u obzir, čini mi se da bi ovakva teorija naišla na jednake probleme neovisno o spolu autora, no to pitanje svakako ostaje otvoreno interpretaciji, čemu su neki autori (Stivers, 1996) pridali posebnu pozornost.

Još jedan razlog manjka njezine popularnosti nalazi se u tome što je - za razliku od znanstvenog menadžmenta, čije su metode bile specifične, a rezultati vidljivi u kratkom roku (Feldheim, 2004) - njezina teorija zahti- 
jevala strpljenje i kreativnost, bila je otvorena interpretaciji i orijentirana na proces, a ne na rezultate. Follett nije razvila tehničke metode, niti alternative ako integracija zakaže. Fox (1968) zaključuje kako se čini da smo, kada se to dogodi, ipak prepušteni dominaciji ili kompromisu. Sama Follett svoju je teoriju nazvala istovremeno konzervativnom i radikalnom (Follett, 1930). Konzervativnom jer se ne može postići revolucijom, zahtijeva edukaciju te je spor proces, a radikalnom jer se tom procesu mora pružiti prilika, što znači da predstavlja određeni rizik budući da iza njega ne stoje empirijska istraživanja kao jamstvo uspjeha.

Međutim, empirijska istraživanja pojavila su se u šezdesetim i sedamdesetim godinama 20. stoljeća i potvrdila mnoge teze koje je Follett iznosila desetljećima prije (Parker, 1984). Prvo, sistemski pristup, odmaknuvši se od mehanicističkog modela organizacije, naglasio je ključnu važnost odnosa među elementima organizacije, a u svojoj kompleksnijoj varijanti i svojstvo sustava da regulira sam sebe - upravo tu poziciju Follett neumorno zastupa kroz sva svoja djela. ${ }^{9}$ Drugo, prominentni autori biheviorističkog smjera u proučavanju organizacije svoja zapažanja izvode upravo iz njezine teorije: Likert, McGregor, Lawrence, Lorsch, Bennis i mnogi drugi u svojim se djelima pozivaju na njezine ideje (Miner, 2006).

Kritika koja se Follett najčešće upućuje jest pretjerani idealizam, osobito u pogledu razvijanja zajedničke moći, pri čemu joj se predbacuje da je ostvarenje nadmoći vječni ljudski impuls (Witt, 2007), čime zajednička moć ostaje plemenitim, ali nedostižnim idealom. Općenito, ti kritičari smatraju da ljudska priroda, zbog svojih inherentnih individualističkih težnji i želje za nadmoći, predstavlja prepreku integrativnom, funkcionalnom jedinstvu, koji Follett smatra mogućim. Ona je definitivno idealistkinja, no u tom idealizmu nije naivna, kakvom su je svojevremeno neki kritičari (Smith, 1925) pokušavali prikazati. Njezina teorija nastala je kao rezultat dugogodišnjeg praktičnog iskustva u radu s ljudima različitog porijekla i društvenog statusa i prošarana je mnogobrojnim anegdotama o ostvarenim integracijama u profesionalnom i privatnom životu. Kroz svoja djela Follett kontinuirano pokazuje istančanu percepciju za kreativna rješenja koja su moguća u međuljudskim odnosima. Unatoč tome, ona razumije da integracija nije uvijek moguća (Metcalf \& Urwick, 2013). Kreativno iskustvo u mnogim je slučajevima nedostižni ideal, no to ne znači da od njega trebamo odustati - svjesni kako ga nikad ne možemo u potpunosti ostvariti, ono predstavlja smjernice po kojima se trebamo truditi djelovati.

9 »Funkcionalno povezivanje kontinuiran je proces koherentnosti koja sama sebe stvara. Većina moje filozofije sadržana je u toj rečenici.« (Metcalf \& Urwick, 2013, 200). 
Širina utjecaja $i$ ocjena relevantnosti. Follett je predvidjela mnoge moderne smjerove u razvoju teorije organizacije i menadžmenta, a posebno je zanimljiv njezin pogled na vođenje $\mathrm{u}$ organizaciji, koji potpuno odgovara teoriji transformacijskog stila vođenja, koja se pojavila u 1980-ih (Ilić, 2008). Prema toj teoriji, transformacijski je vođa »prilagođeniji suvremenim uvjetima poslovanja i usmjeren na organizacijsku viziju koja se ostvaruje mobilizacijom i sinkronizacijom emocionalne energije suradnika u sinergijskom djelovanju svih članova tima« (Ilić, 2008, str. 584). Kad piše o vođenju, Follett opisuje transformacijskog vođu, ${ }^{10}$ dok sinergijsko djelovanje u ovom smislu potpuno odgovara djelovanju u funkcionalnoj cjelini, za čije je stvaranje vođa najviše odgovoran (Metcalf \& Urwick, 2013).

Isto tako, njezino naglašavanje potrebe edukacije i motivacije radnika može se promatrati kao važan doprinos razvoju upravljanja ljudskim potencijalima. Follett vjeruje da posao može i treba doprinositi samoaktualizaciji, iako se ne koristi tim pojmom. Ona želi radnu atmosferu u kojoj se radnici ne osjećaju kao kotačići u stroju, nego kao cjelovite osobe čiji se interesi i ciljevi mogu povezati s ciljevima industrije u kojoj rade (Metcalf \& Urwick, 2013).

Zanimljiv je podatak o popularnosti i priznanju koje je Follett doživjela u Japanu, gdje je, zajedno s teorijom W. E. Deminga, njezina teorija poslužila kao doprinos razvoju upravljanja totalnom kvalitetom (TQM), prakse koja je revitalizirala japansku industriju 1950-ih i 1960-ih (Henry, 2016), te u toj državi slovi kao poznata i cijenjena autorica u teoriji menadžmenta (Enomoto, 2003). Njezino zalaganje za tretiranje radnika s poštovanjem i veću participaciju i kooperaciju u radnim procesima pomoglo je stvaranju paradigme kvalitete (koja je zamijenila tradicionalnu paradigmu na kojoj se zasnivao znanstveni menadžment), na kojoj se temelji TQM (Feldheim, 2004). Follett je također imala bitan utjecaj na upravljanje konfliktima te se na tom području smatra začetnicom integrativnog pregovaranja (Feldheim, 2004).

Iako najčešće nije eksplicitno pisala o organizacijskoj etici (Melé, 2006), u njezinim radovima može se pronaći trag misli koja je dovela do razvoja utjecajne teorije interesnih skupina (stakeholder theory) (Melé, 2006). Follett tako navodi razne skupine s kojima menadžer mora surađivati. ${ }^{11}$

10 Vidi podnaslov 2.7. Timski rad i uloga vođe u organizaciji.

11 Follett navodi tri interesne klase: radnike, potrošače i investitore, koje potom proširuje na bankare, dioničare, druge menadžere i direktore, radnike, konkurentske tvrtke, dobavljače i klijente (Metcalf \& Urwick, 2013). 
Ne koristi se izrazom dionici (stakebolders), ali govori da je menadžer u odnosu sa svim tim skupima, te kao njegovu dužnost navodi pronalazak metode za integriranje interesa svih skupina kao doprinos kreativnom društvenom razvoju (Metcalf \& Urwick, 2013).

Teorija M. P. Follett relevantna je i za probleme s kojima se tipično susreću upravne organizacije. Jedan od većih izazova za javnu upravu predstavlja potreba za kvalitetnijom participacijom građana u njezinu radu (Morse, 2006), pri čemu ideje koje je Follett iznosila mogu poslužiti kao korisne smjernice. Njezina teorija u kontekstu javne uprave uključuje stvaranje svijesti o pripadanju zajednici, koja se mnogo više ostvaruje neformalnim, spontanim kontaktima (primjerice volontiranjem) nego formalnim sastancima između uprave i građana - uprava mora prići građanima, a ne obratno (Morse, 2006). »Susjedstvo ne čine redovi kuća i ulica«, pisala je Follett. Mora postojati »svijest o postojanju prave zajednice« ljudi koji čine susjedstvo (Follett, 1918, 204). Tu je svijest moguće razviti redovitim sastancima na kojima građani, raspravljajući o problemima susjedstva, imaju priliku učiti iz vlastitih i tuđih iskustava te, ako je moguće, integrirati svoje pozicije (Follett, 1930). Državu, prema tome, čine integrirane susjedske grupe koje održavaju redovite kontakte s institucijama javne vlasti (Follett, 1918), a osim susjedskih u društvu trebaju biti zastupljene i druge grupe (kulturne, sportske, edukacijske, religijske itd.), budući da Follett smatra kako pojedinac izražava svoj identitet kroz pripadnost mnogim grupama. Istraživanja su pokazala (Elias, 2010) da metode koje je Follett predlagala mogu pozitivno utjecati na jačanje lokalne demokracije i participacije. Ukratko, Follett je predložila izraženi bottom-up pristup participaciji, koju je smatrala metodom demokracije, te je u tom smislu ponudila vrijedan teorijski okvir za razmatranje problema participacije.

Djela Mary Parker Follett odlikuje slikovit i pristupačan stil. Bilo da govori o kompleksnim filozofskim konceptima ili prepričava anegdotu iz privatnog života, Follett posjeduje istančan dar za zanimljivu i uvjerljivu argumentaciju svojih tvrdnji. Njezini suradnici opisuju je kao fascinantnu osobu koja je živjela u skladu s idejama o kojima je pisala. Redovito je komunicirala s ljudima iz različitih društvenih slojeva, jednako zainteresirana za svako iskustvo te je iz svakog sugovornika znala izvući maksimum (Metcalf \& Urwick, 2013). Iako je Follett u svojoj teoriji vođena neupitnim idealizmom, iz njezinih riječi i podataka koji postoje o njezinu životu, vidi se da je u velikoj mjeri uistinu živjela kreativno iskustvo o kojem je pisala. Važnost njezine misli za suvremenu teoriju organizacije i menadžmenta očituje se u brojnim slučajevima njezine kompatibilnosti s teorijama i praksama koje su i danas vrlo aktualne. Štoviše, smatram 
da njezina teorija može poslužiti kao obuhvatni idejni okvir pristupa modernoj organizaciji, jer na općenit, ali iznimno pronicav način razmatra dinamične okolnosti u kojima se organizacije, a osobito ljudi u njima, nalaze - okolnosti koje se u tom smislu nisu bitno promijenile do danas. $\mathrm{Za}$ razliku od autora koji su iznosili univerzalna načela organizacije koja su potom zastarijevala, načela koja je Follett iznijela djeluju jednako svježe i relevantno kao i prije gotovo stotinu godina kada su prvi put napisana. Probleme organizacije smatrala je fundamentalno ljudskim problemima te je organizacije vidjela kao društveno odgovorne pokretače napretka. Zbog svega toga smatram da Mary Parker Follett zauzima jedinstveno mjesto u teoriji organizacije i menadžmenta te vjerujem da univerzalna kvaliteta njezine misli neće izgubiti na važnosti.

\section{Zaključak}

Mary Parker Follett dala je bogat doprinos teoriji organizacije i menadžmenta, a njezin utjecaj još je uvijek vidljiv u suvremenom razvoju tih disciplina. Ključne teme o kojima je pisala u svojim utjecajnim djelima s početka 20. stoljeća odnose se u prvom redu na proces integracije putem konstruktivnog konflikta, kompleksnu dinamiku međuljudskih odnosa i organizaciju kao funkcionalnu cjelinu, različitu od zbroja svojih dijelova, koju čine pojedinci u dinamičnim, nelinearnim odnosima. Različitosti među pojedincima smatrala je dobrodošlima, a svako iskustvo jednako vrijednim, te je u njima vidjela potencijal za učenje, razvoj i integraciju, koju smatra pokretačem napretka organizacije. Usto, visoko je vrednovala timski rad, a svakog člana organizacije smatrala je integralnim dijelom cjeline, iz čega proizlazi njezin izrazit bottom-up pristup moći i vođenju u organizaciji. Za Follett, vođa je zakon situacije, pojam kojim označava depersonaliziranje naredbi i temeljenje odluka na činjenicama koje članovi organizacije prikupljaju i razmatraju zajednički. Organizaciju je smatrala sustavom koji sam sebe kontrolira i koordinira integrativnom interakcijom svojih članova. Iz tih tema proizlaze njezina temeljna načela organizacije: oslobađanje, interakcija, integracija i izranjanje, kao različiti aspekti istog procesa.

Kronološki, Follett pripada klasičnoj teoriji organizacije, no sadržajno obuhvaća i elemente škole ljudskih odnosa, koje bitno obogaćuje i nadopunjuje elementima teorije sustava, koje je predvidjela s preciznošću koja ih čini kompatibilnima sa suvremenom teorijom kompleksnih sustava. Također, utjecala je na upravljanje konfliktima, vođenje, organizacijsku 
etiku, upravljanje ljudskim potencijalima, upravljanje kvalitetom i participaciju u javnoj upravi te je na tim područjima njezina teorija još uvijek relevantna. Bila je cijenjena tijekom života, no nakon smrti njezina popularnost pada te interes za nju postaje sporadičan, za što postoji niz mogućih razloga: neprimjenjivost njezine teorije u razdobljima pojačane centralizacije, spolna diskriminacija i izostanak tehničkih metoda utemeljenih na empirijskim istraživanjima. Najvjerojatniji je razlog, ipak, idealizam koji prevladava u njezinoj misli, koji ostvarenje njezinih ideja često čini nedostižnima. Unatoč tome, većina autora danas njezinu teoriju smatra iznimno utjecajnom te navode da je Follett bila daleko ispred vremena u kojem je pisala.

Iako je suvremena teorija organizacije i menadžmenta ideje Mary Parker Follett dopunila empirijskim istraživanjima i konkretnijim metodama, smatram da njezina teorija još uvijek nudi mnogo više od povijesne važnosti. Ona predstavlja iznimno pronicav uvid u temeljna pitanja međuljudskih odnosa u organizaciji i kompleksne, dinamične okoline u kojoj se oni odvijaju. Ta pitanja u velikoj mjeri još uvijek čekaju odgovore, a njezin specifični pristup u tome uvelike može poslužiti kao inspiracija. U tom smislu, nedostatak tehničkih metoda može nadomjestiti obuhvatni idejni okvir njezine teorije kao jedna od smjernica pristupu modernoj organizaciji. Esencijalna kvaliteta teorije Mary Parker Follett njezina je nepokolebljiva težnja za društvenim napretkom kroz kreativnu ljudsku suradnju i upravo je u tome njezina najveća vrijednost za moderne organizacije - vrijednost koju ne bi smjele ispustiti iz vida.

\section{Literatura}

Bennis, W. (2003). Thoughts on "The essentials of leadership". U P. Graham. (ur.), Mary Parker Follett: Prophet of management - a celebration of writings from the 1920s (str. 177-181). Washington, D.C. USA: Beard Books

Elias, M. V. (2010). Governance from the ground up: Rediscovering Mary Parker Follett. Public Administration and Management 15(1), 9-45.

Enomoto, T. (2003). The individual in the group. U P. Graham (ur.), Mary Parker Follett: Prophet of management - AcCelebration of writings from the 1920s (str. 240-245). Washington, D.C., USA: Beard Books

Feldheim, M. A. (2004). Mary Parker Follett lost and found - Again, and again, and again. International Journal of Organization Theory and Behavior 6(4), 341362.

Follett, M. P. (1918). The New State: Group organization the solution of popular government. New York USA: Longmans, Green and Co. 
Follett, M. P. (1930). Creative experience. New York USA: Longmans, Green and Co.

Follett, M. P. (2013). Freedom \& co-ordination: Lectures in business organization. New York, USA: Routledge.

Fox, E. M. (1968). Mary Parker Follett: The enduring contribution. Public Administration Review 28(6), 520-529.

Halmi, A. (2002). Kaos i nelinearna dinamika - novi metodološki pristupi u društvenim i politologijskim znanostima. Društvena istraživanja 11(1), 133-154.

Henry, N. (2016). Public administration and public affairs. New York, USA: Routledge

Ilić, E. (2008). Emocionalna inteligencija i uspješno vođenje. Ekonomski pregled 59(9-10), 576-592.

Leavitt, H. J., Pondy, L. R. i Boje, D. M. (1989). Readings in managerial psychology. Chicago, USA: The University of Chicago Press

Melé, D. (2006). Ethics in management: Exploring the contribution of Mary Parker Follett. IESE Business School, The Chair of Economics and Ethics, Working Paper no 618, 1-15.

Metcalf, H. C. i Urwick, L. (2013). Dynamic administration: The collected papers of Mary Parker Follett. Mansfield Centre, CT, USA: Martino Publishing

Miner, J. B. (2006). Organizational behavior 3: Historical origins, theoretical foundations and the future. New York, USA: M. E. Sharpe

Morse, R. S. (2006). Prophet of participation: Mary Parker Follett and public participation in public administration. Administrative Theory \& Praxis 28(1), 1-32.

Parker, L. D. (1984). Control in organizational life: The contribution of Mary Parker Follett, The Academy of Management Review 9(4), 736-745.

Perko-Šeparović, I. (1975). Teorije organizacije. Zagreb, Hrvatska: Školska knjiga

Smith, R. G. (1925). Review of creative experience. The Journal of Social Forces 3(3), 540-542.

Stivers, C. (1996). Mary Parker Follett and the question of gender. Organization: The Interdisciplinary Journal of Organization, Theory, and Society 3(1), 161-166.

Witt, M. T. (2007). Mary Parker Follett: Retrospect \& prospect. Rad predstavljen na konferenciji CMS5 - Management \& Organisation History Stream, Manchester, 11.-13. srpnja 2007.

Yuksel, A. H. (2015). Tracing back the signs of complexity thinking in management: Mary Parker Follett re-visited. Journal of Business, Economics \& Finance 4(3), 523-535. 


\section{THE CONTRIBUTION OF MARY PARKER FOLLETT TO ORGANISATION THEORY AND MANAGEMENT}

\section{Summary}

The theory of Mary Parker Follett, an innovative author of the early 20th century, is outlined and her contribution to organisation and management theory is analysed. Her original works are first presented as an overview of the key themes she addressed, which reflect her creative views on managing differences and conflict among people in organisations, as well as her progressive approach to leadership, power, and control. Her theory is then analysed from different aspects. The relation of her theory to other organisation theories is explored, starting with classical organisation theory, of which she is only chronologically part, and moving on to the buman relations school and systems theory, as these represent theories that are much more compatible with her works. It is argued that Follett's view of the complexity of human interactions surpasses that of the buman relations school, and her organic approach to control and coordination is identified as being in line with the contemporary theory of complex, adaptive systems. Possible explanations why her theory was not accepted throughout the 20 th century are considered along with a sporadic interest in her ideas. The explanations include the difficulty of applying ber theory in periods of centralisation, possible gender discrimination, and the lack of technical methods based on empirical research, while the most probable being the idealism that permeates ber thought. Criticism aimed at her theory is also assessed, as well as its potential shortcomings. The scope of her influence on the development of modern organisation and management theory is explored, especially in the fields of conflict management, leadership, organisational etbics, buman resource management, quality management, and participation. Finally, ber relevance to modern organisations is evaluated.

Keywords: Mary Parker Follett, organisation theory, management, conflict, integration 